NBER WORKING PAPER SERIES

THE EUROPEAN CRISIS IN THE CONTEXT OF THE HISTORY OF PREVIOUS FINANCIAL CRISES

\author{
Michael D. Bordo \\ Harold James \\ Working Paper 19112 \\ http://www.nber.org/papers/w19112
NATIONAL BUREAU OF ECONOMIC RESEARCH
1050 Massachusetts Avenue
Cambridge, MA 02138
June 2013

Paper prepared for Bank of Greece Conference, May 23-25, 2013 The views expressed herein are those of the authors and do not necessarily reflect the views of the National Bureau of Economic Research.

At least one co-author has disclosed a financial relationship of potential relevance for this research. Further information is available online at http://www.nber.org/papers/w19112.ack

NBER working papers are circulated for discussion and comment purposes. They have not been peerreviewed or been subject to the review by the NBER Board of Directors that accompanies official NBER publications.

(C) 2013 by Michael D. Bordo and Harold James. All rights reserved. Short sections of text, not to exceed two paragraphs, may be quoted without explicit permission provided that full credit, including $\odot$ notice, is given to the source. 
The European Crisis in the Context of the History of Previous Financial Crises

Michael D. Bordo and Harold James

NBER Working Paper No. 19112

June 2013

JEL No. E00,N1

\begin{abstract}
$\underline{\text { ABSTRACT }}$
There are some striking similarities between the pre 1914 gold standard and EMU today. Both arrangements are based on fixed exchange rates, monetary and fiscal orthodoxy. Each regime gave easy access by financially underdeveloped peripheral countries to capital from the core countries. But the gold standard was a contingent rule - in the case of an emergency like a major war or a serious financial crisis --a country could temporarily devalue its currency. The EMU has no such safety valve. Capital flows in both regimes fueled asset price booms via the banking system ending in major crises in the peripheral countries. But not having the escape clause has meant that present day Greece and other peripheral European countries have suffered much greater economic harm than did Argentina in the Baring Crisis of 1890.
\end{abstract}

Michael D. Bordo

Department of Economics

Rutgers University

New Jersey Hall

75 Hamilton Street

New Brunswick, NJ 08901

and NBER

bordo@econ.rutgers.edu

Harold James

History Department and Woodrow Wilson School

Princeton University

Princeton NJ 08544

hjames@princeton.edu 


\section{The European Crisis in the Context of the History of Previous Financial Crises}

Michael Bordo, Rutgers University

Harold James, Princeton University

Paper prepared for Bank of Greece Conference, May 23-25, 2013

This paper places the analysis of the European financial crisis in the context of previous international financial crises. It brings together three strands of literature that are normally treated separately: on the macroeconomic context of the gold standard; on microeconomic financial sector linkages; and on the domestic and international political economy of exchange rate regimes.

The parallel between the classical gold standard and EMU has frequently been made. Sometimes in a positive way. Many of the key political figures who drove forward European monetary integration admired the discipline and certainty of the gold standard. French President Valéry Giscard d'Estaing drew on the Gaullist tradition of seeing gold as the embodiment of sound money principles: "During the second half of the nineteenth century, up to the 1914 war, France enjoyed continuously successful economic growth, and a steady build-up of its engineering industry, with a currency that was totally stable. With their roots in a rural economy and their cultural leaning towards the fundamental values of savings and thrift, the French as a nation 
cannot cope with an inflationary economy and a weak currency. They thrive on stable money". German Chancellor Helmut Schmidt put the point in this way: "We had a currency union up to 1914 in Western Europe - the Gold Standard. From a historical point of view, I would draw a direct parallel." (Marsh 2009)

More recently, the comparison is more usually a negative or hostile one. The intent is to demonstrate the unrealizability or absurdity of the constraints that rigid monetary systems impose (Krugman 2013), or the problems of an asymmetric adjustment process (Eichengreen and Temin 2010). These parallels emphasize the interwar experience with a managed gold exchange standard, rather than the classical gold standard.

I Systemic Requirements and Benefits

Adherence to the gold standard, and to EMU, involved an acceptance of:

- monetary orthodoxy: in the gold standard, the constraint is the convertibility of claims into a metallic equivalent; in the modern monetary union, it is imposed by a central bank with a price stability target (in reality since May 2003 defined as "inflation rates below but close to 2 percent over the medium term").

- fiscal orthodoxy: both regimes depend on the avoidance of fiscal deficits that would place the monetary objective in danger. In the gold standard era, most states had little 
room (little technical capacity or political consent) to raise large amounts in taxation, and orthodoxy meant in practice a constraint on spending. Nevertheless, spending continued to increase, and more advanced states began to experience a pressure to undertake some sorts of social spending (before that, the major areas of expenditure were debt service and war). Adolf Wagner formulated a law of increasing state spending. Though government spending rose, economic growth meant that for most countries, the share of government debt of GDP was falling, despite the arms race in the years immediately before the First World War that contributed to a rise in government spending in the major European powers (Figures 1 and 2). The modern EMU occurred in the context of much higher spending levels and higher levels of government debt in all industrial countries, as well as of continual social and political pressure to expand government spending.

The benefits of the gold standard, which became widely adopted in the last third of the nineteenth century, were seen as lying in:

- ease of a common monetary standard

- access to capital markets (overcoming "original sin" that made financially immature economies unable to borrow abroad except in foreign-denominated currency)

- reduction of borrowing costs. 
The initial discussion about the gold standard in the 1860s and 1870s was cast primarily in terms of the ease of a common monetary standard. As the system established itself, membership in the club became an increasingly attractive prize, and countries often went through a period of substantial rigor or austerity as they adopted the rules of monetary and fiscal orthodoxy and hoped for the reward of lower borrowing costs. Ivan Vyshnegradsky, Russian Finance Minister from 1887 to 1892, explained the budgetary and monetary deflation that was needed to bring Russia onto gold as "we must export though we die." (von Laue 1969, 27) In modern Europe, Romano Prodi as Italian Prime Minister and his Treasury Minister Carlo Ciampi, justified a Maastricht tax in 1996-7 in a similar way as an unpleasant medicine that needed to be swallowed, and the international financial markets enthused that - as the Financial Times put it - "at last Italy is close to a virtuous economic path."

The gold standard was based on a contingent rule (Bordo and Kydland 1995). In some unusual circumstances, above all the event of a major war, the commitment to gold convertibility would be temporarily suspended, but with an expectation of an eventual return to convertibility without a change in the exchange rate on the restoration of "normalcy". The model for this behavior was given by the British example, in which convertibility was suspended in the French Revolutionary War in 1797, and restored in 1817 (at the old parity). Britain followed this model in 1914, with a return to the old parity in 1925 . The rule is contingent in the sense that the public understands that the suspension will only last for the duration of the wartime 
emergency plus some period of adjustment. It assumes that afterwards the government will follow the deflationary policies necessary to resume payments at the original parity. In the gold standard, the major fiscal event that would push up debt temporarily was war, which had a clearly definable beginning and end. By contrast, in the modern EMU, the political pressure that increased government spending was not in any way analytically distinguishable from "normalcy" and there was thus a blurry sense of what might constitute exceptional circumstances.

The contingent rule gave a safety valve for fiscal policy in dealing with exceptional circumstances. Following such a rule allows the government to smooth its revenue from different sources of finance: taxation, borrowing, and seigniorage (Lucas and Stokey 1983; Mankiw, 1987).

The operation of the gold standard was seen in a convergence of bond yields. The convergence was never complete, and in particular there is a clear core/periphery divergence. (Bordo and Flandreau 2003) (Figure 3) Peripheral countries always faced the risk of exit, though many countries from the European periphery after they abandoned the formal commitment to a gold parity in fact maintained exchange rate practices which shadowed the gold standard parities (this was the practice in Italy, Portugal, and Spain).

There were also divergences of interest rates within a single monetary area and a single country. The U.S. had large regional interest rate divergences until the post civil 
war era. The internal spreads between the north and the south in the early nineteenth century were probably larger than between the core countries (Davis 1965). Even in the early years of the Federal Reserve System, member banks set different discount rates. The small differences that existed in central bank discount rates of the European core of the gold standard, the UK, France and Germany should not be interpreted as evidence of a market assessment of the likelihood of departure from gold, but rather as evidence of an incomplete integration of capital markets, even on a national level.

The experience of countries with "original sin" (Eichengreen and Hausmann 1999) - in other words countries that did not have sufficiently deep capital markets to borrow in their own currency - can be divided into two groups. In the pre-1914 period, one group includes countries such as Argentina, Brazil, Chile, Italy and Portugal each of which suffered a financial catastrophe between 1880 and 1913. The other group, including Australia, Canada, New Zealand, Norway, and the US had relatively little trouble with financial crises in terms of frequency or virulence (Bordo and Meissner 2007). This differential cannot be explained in terms of differing debt levels. Indeed after a certain point more hard currency debt relative to the total seemed to be associated with fewer debt crises and banking crises. Three or four categories seem to be apparent. The financial centers with low original sin and strong financial fundamentals obviously avoid crises. Other highly developed countries that are small in terms of global output, and carry high original sin also avoid severe financial crises. In terms of less developed countries, there are many which are relatively closed to 
external capital flows or have yet to kick start the development process. These countries also have original sin like the rest of the world but are not prone to volatile capital movements. The most dangerous combination seems to be high original sin in an emerging market. Such countries were characterized by what Reinhart and Rogoff (2009) term debt intolerance. But that effect could be counteracted by some measures: in particular political integration in the international state system. Reinhart and Rogoff note how "recovery [from financial crises] may take decades or even centuries" in the absence of an "outside political anchor" (they give as cases of such successful anchoring the effect of the European Union on countries like Greece and Portugal: p. 30). The monetary regime is inevitably part of a general concept of international order.

\section{The Risks of the Classic Gold Standard}

Large-scale emerging market borrowers ran a substantial risk of entering into an unstable dynamic with a destabilizing fiscal policy that might threaten the maintenance of the rules of the game. The gold standard experience is filled with sudden stops of capital inflows in which advanced country creditors either hit by domestic shocks or fearful of events in the borrowing countries turn off the lending spigot (Bordo 2006). 1890 was a turning point, after which creditors became more concerned with fiscal sustainability than with development potential (Flandreau and Zumer 2004) 
The turning point in 1890 was the result primarily of a crisis in Argentina. In the late 1880s Argentina had experienced a major boom, with substantial borrowing to develop the potential of the pampas. A modern calculation suggests that Argentina imported capital amounting to $18.7 \%$ of its GDP between 1870 and 1889 (the other big importers of capital were Australia, 9.7\%, and Canada 7.2\%, over this period) (Flandreau and Zumer 2004). By the 1880s, Argentina accounted for almost half of British foreign lending (Ford 1963; Mitchener and Weidenmier 2006). By the end of the 1880s, Argentine public finances were increasingly strained, with the cost of financing the federal deficit amounting to 68 percent of government expenditure by 1889 . Subsidiary government institutions continued to borrow even when the federal government promised not to borrow more without the consent of the bankers. All Argentine short term borrowing became much more expensive, and long term bond issues impossible. Bank credit creation, which had been regulated under an 1887 Law of National Guaranteed Banks in which banks issued notes backed by gold denominated government debt, represented another weak point of the Argentine structure. The crunch came when the largest and most prestigious London merchant bank, Barings, which had been handling Argentine debt issue since 1824, failed to sell the bonds of the Buenos Aires Water Supply and Drainage Corporation, and faced a substantial loss on its underwriting that threatened the solvency of the bank. The government was unable to make gold payments, and paid instead in depreciated paper. Thus the gold standard rule was violated, and the access to further borrowing was radically shut down. Without access to more finance, the economy collapsed, and 
political unrest brought down Juarez Celman, the President of the Republic, in 1890. The contraction was very sharp, indeed in terms of real GDP sharper and more sudden than anything in the recent financial crisis, but growth resumed quite quickly, and by 1893 pre-crisis real GDP levels were attained. It was only in 1893 that the Argentine debt was restructured (in the arreglo Romero), with a deferral of most payments for ten years and a reduction of interest payments for five years; and only in the new century that capital flows to Argentina really resumed.

After 1890, as Flandreau and Zumer (2004) document, as a response to the Argentine crisis and its aftermath, investors focused less on judgments about the inherent possibilities of development in a borrowing country than on the extent of the institutional commitment to a low deficit budget regime. What determined the sustainability of inflows, and was it just a matter of following good policy?

1. The flows almost always produced an expansion of the banking system in the importing country. That expansion could turn into a source of instability if banks became unable to repay credits, either because of a liquidity or a solvency problem. When countries credibly adopted the gold standard, they often experienced surges of capital inflows. These were almost always mediated through the financial system. Sudden stops, were sometimes caused by banking sector weakness, and sometimes lead to bank collapses. They did not inevitably end the exchange rate commitment. There was thus a close association between capital flows and banking crises (Figure 4). 
For instance, when Italy returned to convertibility after a period of suspensions following the Austrian war of 1866, the move sparked off a substantial surge in growth, financed in large part by inflows of foreign credits, and a real estate boom. There was a substantial current account deficit, reflecting the inflows of external money. Between 1882 and 1887, the lending of commercial banks increased by 15 per cent a year (Toniolo 1990, p. 77). When the boom slowed down in 1887-88, the Italian banks ran into great difficulties. The inflows now stopped, in 1892 there was a sharp drop in GDP, while the current account moved into surplus in 1891 and 1892. The sudden stop was fundamentally unsustainable in the political and economic circumstances of Italy, and a wave of scandals and crises erupted that required a complete reorganization of Italian banking, with a new central bank (the Banca d'Italia) taking the place of the previous banks of issue, and new commercial banks. 1893 was a major financial crisis in which the two largest commercial banks, the Credito Mobiliare and the Banca Generale, failed, in addition to one of the note-issuing banks, the Banca Romana. For most of the period following the re-establishment of the gold standard, the lira-sterling and lira-pound exchange rate was very close to parity, but after June 1893 the exchange rate fell sharply. The depreciation of the lira reached as much as 13 percent. The subsequent bank reform led on the one hand to the creation of a new major note-issuing bank, the Banca d'Italia, which absorbed the Banca Romana; and to the institution of new mixed or universal banks, explicitly copied from the German model, and financed by international consortia in which the German financial establishment was preponderant. The new banks, the Banca Commerciale Italiano (1894) and the Credito Italiano (1895), 
were intended to contribute to the financing of industrial development. In practice they set off a new wave of capital inflows, that lasted until the next financial crisis.

Another example of the perils of banking expansion was provided by Australia, which experienced a massive capital inflow from Britain to fuel a wool and mutton driven boom in pastoral land. The land mortgages were financed by pastoral finance companies and mortgage banks. The Australian commercial banks (some of which were based in London) in turn funded these institutions. They obtained their funding from deposits of British (largely Scottish) savers who believed that the Australian banks were similar to those in Britain, in the sense that they followed the real bills doctrine and did not make mortgage loans. When the global terms of trade turned down in the late $1880 \mathrm{~s}$ and wool prices fell this decimated the balance sheets of the pastoral finance companies and then quickly spread to the banking system evident in the failure of the Mercantile Bank of Australia in 1892 and a banking panic in 1893. Large losses to the British depositors led to a major sudden stop to Australia which lasted for a decade (Bordo and Meissner 2012).

The consequences of capital inflows and an explosion of bank lending is visible in the case of the largest and most persistent debtor country of the nineteenth century, the United States. The U.S. banking system based on small unit banks was notoriously unstable and volatile and there were frequent banking panics. Indeed the panic of 1873 followed a sudden stop of British capital which had financed the development of the railroads across the west after the Civil War. The boom was associated with a corporate 
governance scandals since many railroads engaged in "tunneling" between their finance holding companies and the railroads (Bordo and Benmelech 2008) as well as political corruption (such as in the case of the 1832 American Crédit Mobilier scandal) (Glaeser and Goldin 2007). Many banks were involved with the affected railroads. News of the scandal led to a sudden stop of British capital, a stock market bust, and the panic. But, perhaps with the exception of the mid 1890s at the height of the political agitation for Free Silver (Hallwood MacDonald and Marsh 2012), there was no doubt about the maintenance of the parity consistent with gold standard rules.

2. A strong and effective state could underpin a banking system, and thus allow greater volumes of borrowing to continue for longer and with greater sustainability. In Russia, the State Bank was widely regarded as a reinsurance mechanism that would bail out problematical private debtors: it was often referred to as "the Red Cross of the bourse" (Crisp 1976). Thus Russia had large inflows, and a sudden stop, but no suspension of convertibility.

How is state effectiveness measured? There is both an internal and an external component. The internal prerequisites relate to capacity to tax or raise other revenue. The external component depended on relations with a major power which could provide an anchor of financial stability.

3. International diplomatic commitment enhanced the market perception of state effectiveness. Alliance links offered to investors the security that creditor governments 
would put pressure on banks to continue lending, and hence reduced the likelihood of sudden stops.

The story of how diplomatic commitments enhance credibility is especially evident in the well-known case of Russia. The beginning of the diplomatic rapprochement of Russia with France in 1891 was accompanied by a French bond issue, which the supporters of the new diplomacy celebrated as a "financial plebiscite" on the Franco-Russian alliance. Russia survived a sharp contraction in 1900-01, as well as a political crisis with war and revolution in 1905, with no default. It raised new money immediately after the revolution of 1905. By 1914, almost half of the $1733 \mathrm{~m}$. ruble Russian government debt was held abroad, and four fifths of that was in French hands, with the UK holding 14 percent. The diplomatic, military and financial calculations were intricately tied together, and were skillfully used by Russia as a way of locking in the creditors politically and economically.

In imperial systems, the imperial security umbrella, coupled with the extension of legal principles from the metropol, functioned in a similar way and reaasured investors that the country was capable of sustaining greater debt levels. The effect has been attributed to imperial order, but it is hard to determine whether it is more due to the effects of good policy, imposed as a result of reform minded administrators, or of the power of the empire to compel repayment. (Ferguson and Schularick 2006). In the aftermath of some crises, the imperial system simply expanded to swallow up bankrupt debtor entities: well known example are Egypt in 1875, or Newfoundland in 1933. In an 
extreme example in early 1915, the Russian government suggested a fiscal and political union with France and UK to allow it continued access to credit markets (Siegel forthcoming).

4. Popular political discontent eventually limited the possibility of adjustment policy. The Tsarist empire was an effective and capacious borrower, it never seemed to violate the gold standard rule in peacetime, but it was brought down by massive social discontent that was in large part driven by the widespread perception that its policy had been sold out to foreigners. A major part of Lenin's analysis, for instance, was devoted to the demonstration that Russia had become a quasi-colony as a result of the large scale capital imports, and that the foreign creditors in effect controlled Russia's foreign policy.

The linkages of these issues can be summarized as a series of impossible trinities or trilemmas (on political trilemmas see Rodrik 2007).

The trilemmas:

1. The macroeconomic classic: fixed exchange rates, capital flows, autonomous monetary policy

2. The financial sector: fixed exchange rates, capital flows, financial stability

3. The international relations setting: fixed exchange rates, capital flows, national policy independence

4. The political economy: fixed exchange rates, capital flows, democratization 
III. What happened in the interwar years?

All four of these trilemmas became more obviously impossible after the First World War.

1. The best known macro-economic interpretation of the interwar problem emphasizes the much more pronounced asymmetry of the adjustment problem in the managed gold exchange standard of the 1920s (Eichengreen 1992). The active monetary management by central banks in France and the U.S. meant the sterilization of gold inflows, while deficit countries, including the UK and most central European and Latin American countries faced a pressure to deflate when capital markets were no longer available.

2. Financial intermediation chains were weaker because of the inherently weak positions of banks in many borrower countries. Inflation and hyper-inflation destroyed the capital basis of many financial institutions. Austrian, German and Hungarian banks 
were thus much more weakly capitalized than they had been before the First World War, and were consequently more vulnerable than they had been in the era of the classic gold standard.

The intermediation chains also became more complex. A consequence of the First World War had been the development of small neutral countries, in particular the Netherlands and Switzerland, as the locus of financial intermediaries. These intermediaries had regulatory and fiscal attractions, as well as offering greater currency stability. It was thus a regular practice for German corporations and banks to create affiliates and subsidiaries in Amsterdam and Zurich, deposit funds with them, and then borrow from those affiliates or subsidiaries. They had similar credit relations with some institutions that they did not own or control. Moments of crisis - as in 1931 produced large inflows to these neutral intermediaries, without any onward lending. In these circumstances, the Swiss and Dutch banks lived with the possibility that there would be an outflow of deposits (James 1986).

3. Policy credibility could be enhanced by signing into the international system - as in the pre-1914 days. Taking on commitments was a way of enhancing credibility for lenders. Thus, for instance, Germany appeared to have a much greater worthiness when its parliament (the Reichstag) accepted the Dawes Plan in 1924 and the provisions of the London conference by the special majority (two thirds) required for a constitutional alteration. Or, in another example, Italy under the fascist leader Benito 
Mussolini gained market access when it not only stabilized the currency against gold, but also (temporarily) abandoned its expansionist and revisionist rhetoric.

4. Enhancing credibility through international commitment might bring a heavy price in domestic political terms. The domestic price was higher because of the other policy trilemmas: deflation made adjustment more painful. The result of the social and political pain was that discontent was focused on the international order, and that radical parties demanded a nationalist and populist alternative.

\section{The EMU Story}

The move to monetary union for weaker countries was a credibility enhancing mechanism that would lower borrowing costs. For countries that had strong creditor positions, the attractions of monetary union lay in the depoliticizing of the adjustment process.

At the beginning, in the Bretton Woods era of fixed exchange rates and controlled capital markets, even relatively small deficits could not be financed, and produced immediate pressure on the exchange markets. The deficit countries then had to apply fiscal brakes in a stop-go cycle. Germany's partners, notably France, were faced by the prospect of austerity and deflation in order to correct deficits. This alternative was unattractive to the French political elite, because it constrained growth 
and guaranteed electoral unpopularity. Their preferred policy alternative was thus German expansion, but this course was unpopular with a German public worried about the legacy of inflation and was opposed by the powerful and independent central bank, the Deutsche Bundesbank. Solving the question of the German current accounts in the European setting at first appeared to require some sophisticated and ingenious political mechanism, that would force French politicians to do more austerity than they would have liked, and Germans less price orthodoxy than they thought they needed. A political mechanism however requires continual negotiation and public deliberation, and that would have been painful given the policy preferences in the two countries (and in those countries that lined up with each one of the Big Two). The increased attraction of monetary union was that it required no such political process, and that the operation of an entirely automatic device would constrain political debate, initiative and policy choice. The monetary union occurred in the aftermath of an era of capital market liberalization, in which current account imbalances were sustainable for much longer periods. The effects of movements in capital in allowing current account imbalances to build up to a much greater extent, and ensuring that corrections, when they occurred, would be much more dramatic, was already noticeable in the late 1980s and early 1990s, before the move to monetary union. Indeed, those large build-ups in the imbalances were what convinced Europe's policy-makers that a monetary union was the only way of avoiding the risk of periodic crises with currency realignments whose trade policy consequences threatened the survival of an integrated internal European market. 
Monetary discipline was built into the new European order, which was founded on a strong assertion of the primacy of price stability as the objective of the central bank. Fiscal stability was the subject of intense debate at both a theoretical and a policymaking level. Prior to the monetary union, an extensive discussion had taken place as to whether fiscal discipline could be imposed by market pressures alone. In the context of the Delors Committee, a memorandum prepared by the BIS General Manager Alexandre Lamfalussy stated:

“With widely divergent 'propensities to run deficits' prevailing in the various European countries, I doubt whether we could count in the foreseeable future on a convergence within a European EMU similar to that observed in most contemporary federal systems. Nor do I believe that it would be wise to rely principally on the free functioning of financial markets to iron out the differences in fiscal behavior between member countries: (a) the interest premium to be paid by a high-deficit member country would be unlikely to be very large, since market participants would tend to act on the assumption that the EMU solidarity would prevent the "bankruptcy" of the deficit country; and (b) to the extent that there was a premium, I doubt whether it would be large enough to reduce significantly the deficit country's propensity to borrow. There is, therefore, a serious risk that, in the absence of constraining policy co-ordination, major differences in fiscal behaviour would persist within a European EMU. This would be one contrast between most contemporary federal systems and a European EMU. [...] Such a situation would appear even less tolerable once the EMU was regarded as part and parcel of the world economy, with a clear obligation to co-operate with the United States and Japan in an attempt to preserve (or restore) an acceptable pattern of external 
balances and to achieve exchange rate stabilisation. To have the smallest chance of reaching these objectives, all co-operating partners need flexibility in the fiscal/monetary policy mix - as we have so often told the United States. In short, it would seem to me very strange if we did not insist on the need to make appropriate arrangements that would allow the gradual emergence, and the full operation once the EMU is completed, of a Community-wide macro-economic fiscal policy which would be the natural complement to the common monetary policy of the Community."

In the course of these discussions, the Governor of the Banque de France, Jacques de Larosière suggested as a phrase for the final report: "economic and monetary union without a sufficient degree of convergence of budgetary policies would be unlikely to be durable." But at a later stage, when the final draft was being discussed, he pointed out that there was a problem with the concept of "binding constraints on the size and financing of budget deficits": "who," he asked, "is going to be judge of the enforceability... there is no police." (James 2012) The common fiscal policy never emerged in the Eurozone.

The involvement of monetary authorities in government finance was ruled out by the stipulations of the Maastricht Treaty forbidding the ECB to purchase government bonds, and the absence of support was a vital part of the "no-bailout" philosophy woven into the treaty (Article 104/1 of the Maastricht Treaty, Article 21 of the ECB statute, and Article 104/1 of the Lisbon Treaty). 
After entry into the EMU, bond spreads fell to almost zero (until the outbreak of the global financial crisis), as the ECB was bound to treat all member country bonds equally. (Figure 5)

EMU worked quite well as a disciplining mechanism before it entered into effect, but much less well afterwards. (Figure 6)

A major blow came when France and Germany ignored the Stability and Growth Pact and had it suspended in November 2003 as a counter to a - as it proved spurious threat of recession. EU Commission President Romano Prodi memorably called the Pact "stupid." The European Council agreed not to apply the deficit procedure against France and Germany, though later the European Court of Justice ruled that this step contravened EU law. In 2005, the disciplinary mechanism was softened, many processes became merely discretionary, and new procedural provisions made it harder to take action against non-compliant states (Council Regulations of June 27, 2005, 1055/2005 and 1056/2005). Smaller EU countries were outraged by France and Germany's initiative. But the behavior of the Big Two had a corrosive effect on other countries. While there had been a great deal of fiscal convergence in the 1990s on the Maastricht criteria, in the 2000s (even before the financial crisis) fiscal discipline in Europe deteriorated. Was this just a European phenomenon? The same trajectory occurred in the US, from fiscal responsibility in the 1990s (under President Clinton) to persistent and high deficits in the 2000s under George W. Bush and under Barack Obama in the aftermath of the financial crisis of 2007-8. So other explanations posit that 
the US also provided a bad example, or (more plausibly) that the markets were apparently willing to finance almost limitless amounts of government debt, as they perceived the debt of industrial countries to be an entirely risk-free asset.

In the wake of the transition to monetary union, debt holding became internationalized. Up to the late 1990s and the advent of monetary union most EU government debt was domestically held: in 1998 the overall ratio of foreign held debt was only a fifth. That ratio then climbed rapidly in the aftermath of the introduction of the Euro. In 2008, on the eve of the financial crisis, three quarters of Portuguese debt, and half of Spanish and Greek debt, as well as over two fifths of Italian debt was held by foreigners. A significant proportion, especially in the case of Greece, Portugal and Italy, was held by banks.

The steps in the gold standard and interwar logic are repeated, with an intensification of the trilemmas:

1. Banking expanded after the establishment of EMU (Shin 2012). No adequate provision on a European basis existed for banking supervision and regulation, which like fiscal policy, was left to rather diverse national authorities. An explosion of banking activity occurred simultaneously with the transition to monetary union and may well have been stimulated by the new single money. A "banking glut" led to a new challenge to monetary policy-making. It produced high rates of growth in Greece, Spain and Ireland, with commentators celebrating Greece as "a giant in the making" 
(Kalaitzidis 2010), the Spanish Miracle, and the Irish "Celtic Tiger". Though there were concerns about asset price inflation, there was no European mechanism for controlling the explosive growth of bank credit. (Figure 7)

2. The bank expansion could go on longer because of implicit government backstop. It was reversed when government debt management no longer looked credible: in the Greek case after the elections of October 2009. In that aftermath of the reversal of expectations, fears about the Greek financial system produced an intermediation through foreign banks, notably in London and in Cyprus, with both assets and liabilities of Greek banks with these financial centers rising (Figures 8, 9, 10).

3. The implicit national government backstop was really only credible because of the international commitment to the European integration project. It was that commitment that led markets to believe that - in spite of the no bailout provisions of the Maastricht Treaty - there were almost no limits to the amount to which debt levels could accumulate both in the private and the public sector. The private sector thus behaved as if there were a bailout provision. As Dellas and Tavlas (2012) put it: “The only way the low risk premia can be justified (ex-post) is by assuming that investors expected the core of the euro zone would have no choice but to bailout Greece in the event of a financial-fiscal crisis." European officials continued to foster this kind of thinking as the crisis grew deeper. Even when confidence in the Greek government's handling of the crisis was beginning to erode, the President of the Eurogroup Jean-Claude Juncker stated boldly: “We're telling financial markets: Look out, we're not abandoning 
Greece." (Lynn 2012, 135) When governments turned round, in particular after the Deauville meeting of Chancellor Merkel and President Sarkozy in October 2010 and demanded a haircut for Greek creditors (or Private Sector Involvement, PSI), the yields immediately diverged further, with dramatic jumps for Italy and Spain whose debt levels had previously been thought of as sustainable (Figure 11). Deauville undid the framework of solidarity that the EU treaties seemed to have created.

4. Cross-border capital flows through the financial system, especially when they take place through small countries where the banking system is substantially larger than the size of the national economy, are potentially dangerous. In the absence of a Europewide resolution system, banks may be too large for national governments to rescue.

5. When the democratic/popular backlash occurs, it takes the form of rejection of international/cross-border political commitment mechanism. Voters are surprisingly discerning. Opinion poll data shows a major increase in hostility to the EU in peripheral countries, but with no corresponding unpopularity of the common currency. Hostility to the EU is also evident in parliamentary elections results in Greece and Italy.

The trilemmas are worse in the recent context because of the absence of an escape clause as under the gold standard. A standard IMF package for instance was usually thought to contain a mixture of exchange rate adjustment to restore competiveness with some measure of debt reduction in order to restore sustainability. There is something classic about this. That combination was characteristic of Argentina's approach to its 
extreme debt crisis in the 1890s. In the absence of an exchange rate option, there is consequently a need for greater debt reduction, but that raises a politically awkward question of the distribution of losses between the private and the public sector.

The result is reminiscent of the interwar political debate about whether (mostly American) private creditors or (mostly European) official reparations creditors should have priority in the payment of German debts. What made the interwar slump so intractable was that it was not just a financial issue, but also a crisis of democracy, of social stability, and of the international political system. It is now clear that contemporary Europe is reenacting the political economy logic of that interwar upheaval.

In the interwar period, increased social tension as a consequence of increased unemployment and of widespread bankruptcy made normal democratic politics impossible. In Germany, the epicenter of the breakdown of democracy, nationalist radicals on both the right and the left raged against the postwar peace settlement and the Versailles Treaty. In the last years of the increasingly unstable Weimar Republic, as democracy was fraying, the German government started to use the radicalism of their opponents as a way of trying to extract security concessions from the western powers. Domestic political pressure became a source of heightened international tension.

That is true in today's Europe. Democracy has become a central target of complaints by the European elite. Luxembourg Prime Minister and former Euro group 
chair Jean-Claude Juncker stated that it wasn't that European leaders didn't know what the right policies were; but that they didn't know how to be reelected after they had implemented them (Economist, 2007). Italian Prime Minister Mario Monti after a humiliating election defeat in 2013 wistfully explained how the Italian electorate was too impatient to bear reforms whose benefits would only become evident over a longer time frame than that of the election cycle (Financial Times 2013). The 2013 Cyprus crisis and its resolution exposed two new dimensions to the clashes over Europe's debt and bank crisis. The discussion of a levy on bank deposits, and whether small customers should be exempted, puts class conflict at center stage. The question of foreign, and especially Russian, depositors - along with the proximity to Syria - makes the incident into an international relations problem.

\section{Conclusion}

The ability to overcome "original sin" and to absorb debt in a sustainable fashion does not lead itself to any easy metric or rule. Institutional arrangements play an important part in shaping the nature of the commitment mechanism. Countries with immature financial markets and evident growth or catch-up potential can increase their ability to borrow by entering into political agreements with powerful creditor countries. The diplomatic ties of Russia before the First World War, or of Germany in the stabilization years after 1924, are precedents for the processes created in the course of 
European integration at the end of the twentieth century. In the course of European integration an apparently even more solid framework for cooperative action was created. Those diplomatic or now supranational commitments however do not change the problems posed by the adjustment requirement, and the asymmetric character of crisis adjustment is more apparent in the modern era (and in the interwar experience) than it was under the classic gold standard. A design that intentionally excluded a contingent clause made the system at first apparently more robust, but aggravated the eventual adjustment issue. That is why the initial crisis may not have been so acute as some of the gold standard sudden stops, such as Argentina's 1890 collapse, but the modern European recovery or bounceback is painfully slow and protracted (Figure 12). The modern system has more deeply embedded institutions that should foster cooperation and looks stronger; and this makes it possible for strains to build up for much longer before the system cracks. When the cracks appear, the damage is deeper. The instability is increased by the heightened complexity and length of credit chains, and by the fact of the mediation of credits through small country banking centers. 


\section{References:}

Bordo, Michael D. (2006) “Sudden Stops, Financial Crises, and Original Sin in Emerging Countries: Déjà vu?" NBER working paper 12393

Bordo, Michael D. and Efraim Benmelech (2008)“ The Financial Crisis of 1873 and 19th Century Corporate Governance" NBER DAE Summer Institute

Bordo, Michael D. and Finn E. Kydland (1995), “The Gold Standard as a Rule," Explorations in Economic History, vol. 32, pp. 423-464

Bordo, Michael D. and Christopher M. Meissner (2007), "Foreign Capital and Economic Growth in the First Era of Globalization," NBER Working Paper No. 13577

Bordo, Michael D. and Christopher Meissner ( 2012) ' Financial Globalization,Financial

Development, Financial Crises and Economic Growth in the Golden Age, 1870-1914"

Slides given at SSHW Stanford University May 2012

Bordo, Michael D. and Hugh Rockoff (1996), “The Gold Standard as a ‘Good Housekeeping' Seal of Approval, Journal of Economic History 56, 389-428.

Bordo, Michael D. and Marc Flandreau (2003), “Core, Periphery, Exchange Rate Regimes, and Globalization," in (eds.) Michael D. Bordo, Alan M. Taylor and Jeffrey G. 
Williamson, Globalization in Historical Perspective, Chicago: University of Chicago Press

Crisp, Olga (1976), Studies in the Russian economy before 1914, New York: Barnes \& Noble Books

Davis, Lance (1965), "The Investment Market, 1870-1914: The Evolution of a National Market." Journal of Economic History 25, pp. 355-399

Della Paolera, Gerard and Alan M. Taylor eds. (2003), A new economic history of Argentina, Cambridge ; New York: Cambridge University Press

Dellas, Harris and George S. Tavlas (2012), “The road to Ithaca: the Gold Standard, the Euro, and the origins of the Greek sovereign debt crisis," Paper at Cato Institute 30th Annual Monetary Conference, Washington D.C., November 15.

Economist, The (2007), "The quest for prosperity," March 15

Eichengreen, Barry (1992), Golden fetters: the gold standard and the Great Depression, 19191939, New York ; Oxford : Oxford University Press

Eichengreen, Barry and Peter Temin (2010), "Fetters of gold and paper," Oxford Review of Economic Policy, vol. 26(3), pp. 370-384

Eichengreen, Barry and Ricado Hausmann (1999), “Exchange Rates and Financial Fragility", in: Federal Reserve Bank of Kansas City (Ed.), New Challenges for Monetary 
Policy, pp. 329-368Ferguson, Niall and Moritz Schularick (2006), “The Empire Effect: The Determinants of Country Risk in the First Age of Globalization, 1880-1913," Journal of Economic History, 66/2, 283-312

Financial Times (1997), Perseverance on Monetary Union is Close to Reward," July 21

Financial Times (2013), "Voters in southern Europe grow weary of austerity," March 3

Flandreau, Marc and Frédéric Zumer (2004), The Making of Global Capital 1880-1913, Paris: OECD Development Centre Studies

Ford, A.G. (1962), The Gold Standard 1880-1914: Britain and Argentina, Oxford: Oxford University Press

Glaeser, Edward and Claudia Goldin (2006), Introduction to Corruption and Reform. Chicago; University of Chicago Press

Hallwood, C. Paul, Ronald MacDonald and Ian W. Marsh (2012), Credibility and fundamentals: were the classical and inter-war gold standards well-behaved target zones?" in Michael D. Bordo and Ronald MacDonald (eds.), Credibility and the international monetary regime : a historical perspective, New York : Cambridge University Press, pp. $71-88$

James, Harold (1986), The German Slump: Politics and Economics 1924-1936, Oxford: 
Oxford University Press

James, Harold (2012), Making the European Monetary Union, Cambridge Mass.: Harvard University Press

Kalaitzidis, Akis (2010), Europe's Greece : a giant in the making, New York: Palgrave Macmillan

Krugman, Paul (2013), “Lust for Gold,” New York Times, April 11, 2013

Lucas, Robert E., Jr. and Nancy Stokey (1983), "Optimal Fiscal and Monetary Policy in an Economy without Capital," Journal of Monetary Economics, 12(1), pp. 55- 93

Lynn, Matthew (2011), Bust : Greece, the Euro, and the sovereign debt crisis, Hoboken, N.J.: Bloomberg Press

Mankiw, Greg (1987), "The Optimal Collection of Seigniorage: Theory and Evidence," Journal of Monetary Economics 20, pp.327-341

Marsh, David (2009), The euro : the politics of the new global currency, New Haven;

London : Yale University Press

Monovoukas, Michael (2012), "Sovereign Debt: Levers Long Enough to Move the Earth," Woodrow Wilson School Princeton Senior Thesis

Obstfeld, Maurice and Alan M. Taylor (2004), Global Capital Markets: Integration, Crisis 
and Growth, New York and Cambridge: Cambridge University Press, 2004

Reinhart, Carmen and Kenneth Rogoff (2009), This Time is Different: Eight Centuries of Financial Folly, Princeton: Princeton University Press

Rodrik, Dani (2007),"The Inescapable Trilemma of the World Economy," in:

http://rodrik.typepad.com/dani_rodriks_weblog/2007/06/the-inescapable.html

Shin, Hyun Song (2012), “Global Banking Glut and Loan Risk Premium," Mundell-

Fleming Lecture, presented at the IMF Annual Research Conference, November 10-11, 2011, IMF Economic Review, 60, pp. 155-192

Siegel, Jennifer (forthcoming), For Peace and Money: International Finance and the Making and Unmaking of the Triple Entente

Toniolo, Gianni (transl. Maria Rees) (1990), An economic history of liberal Italy, 1850-1918 London New York: Routledge

von Laue, Theodore (1963), Sergei Witte and the industrialization of Russia, New York, Columbia University Press 


\section{Charts}

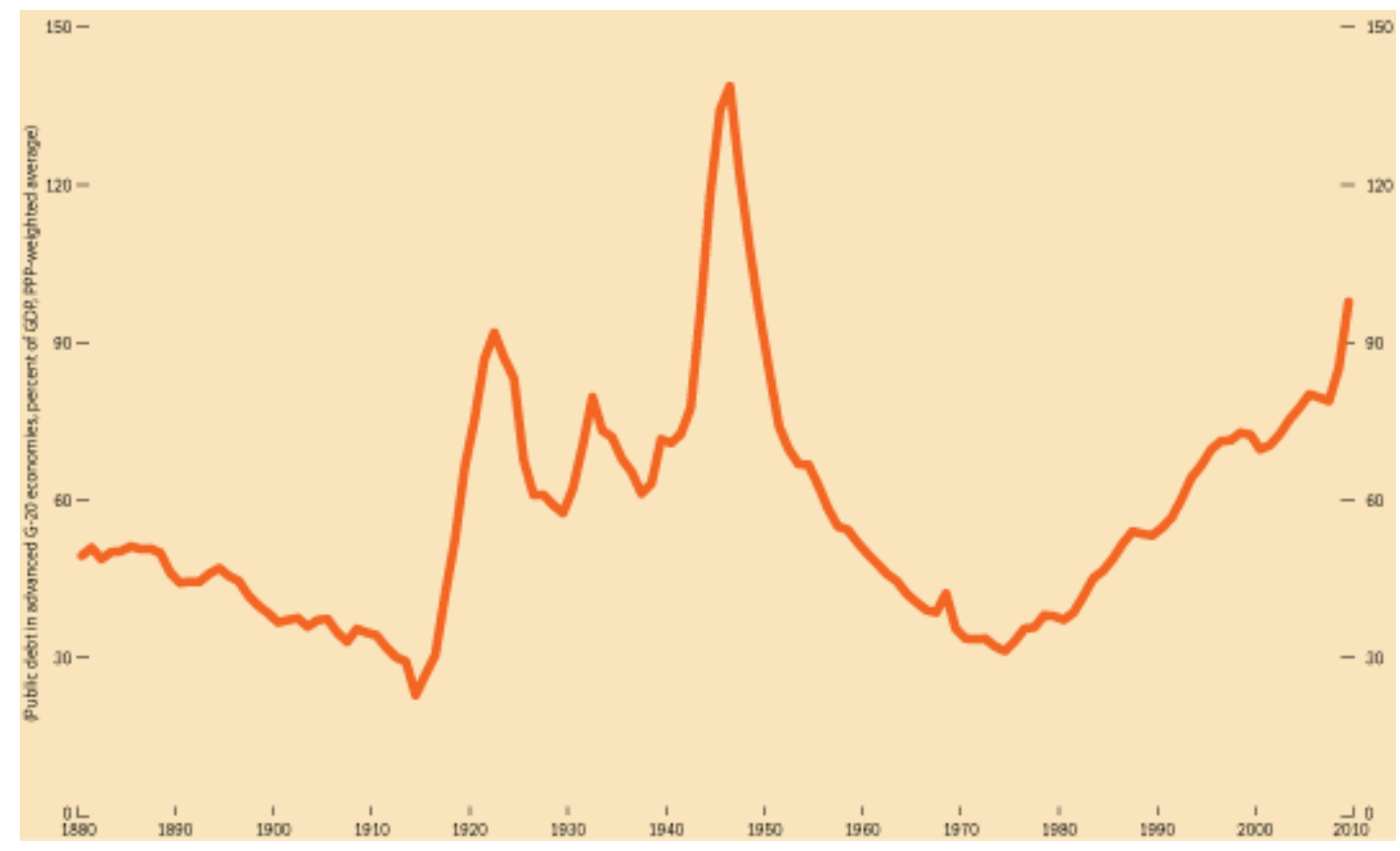

\section{Public Debt as a Share of GDP}

S. Ali Abbas, Nazim Belhocine, Asmaa ElGanainy, and Mark Horton, A Historical Public Debt Database, IMF WP 10/245 


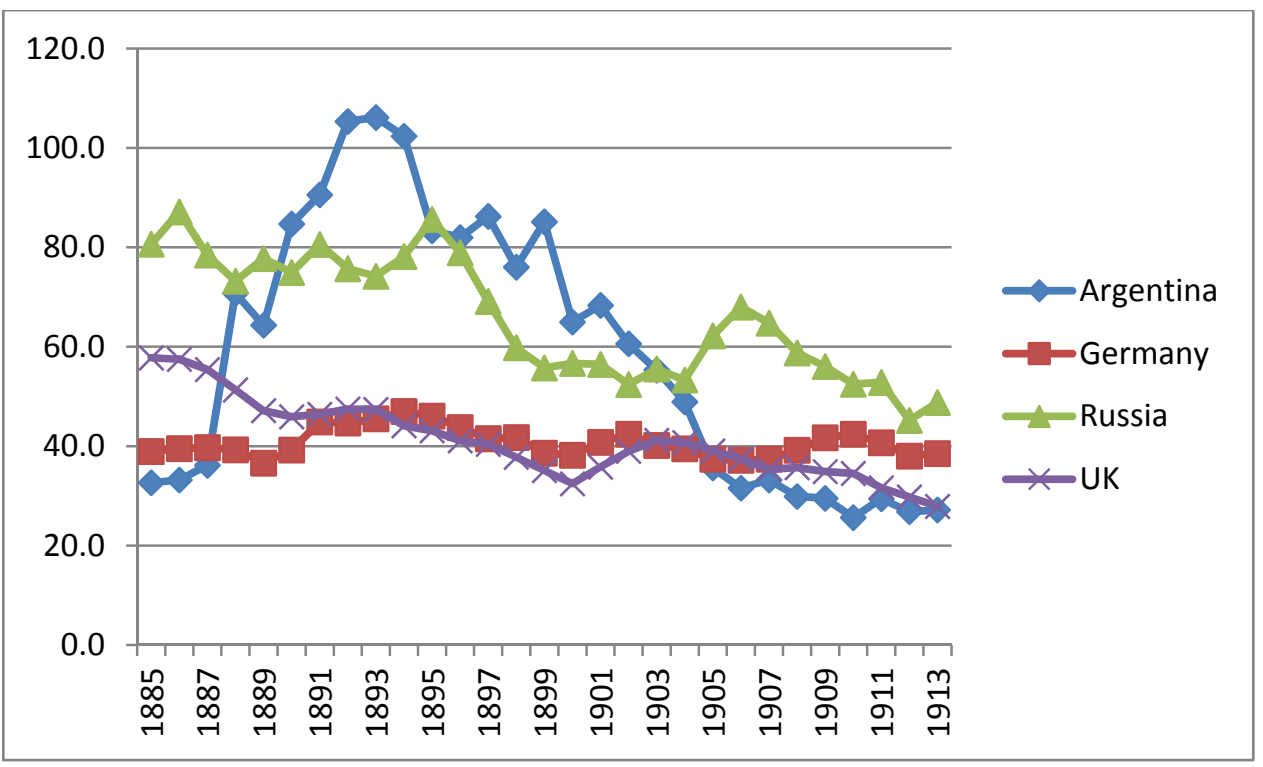

2. Public Debt as a Share of GDP in Gold Standard (IMF Historical Debt Database) 


\section{Bond Yields in Gold Standard}

Figure 8: London Bond Spreads, Core and Periphery, 1870-1940
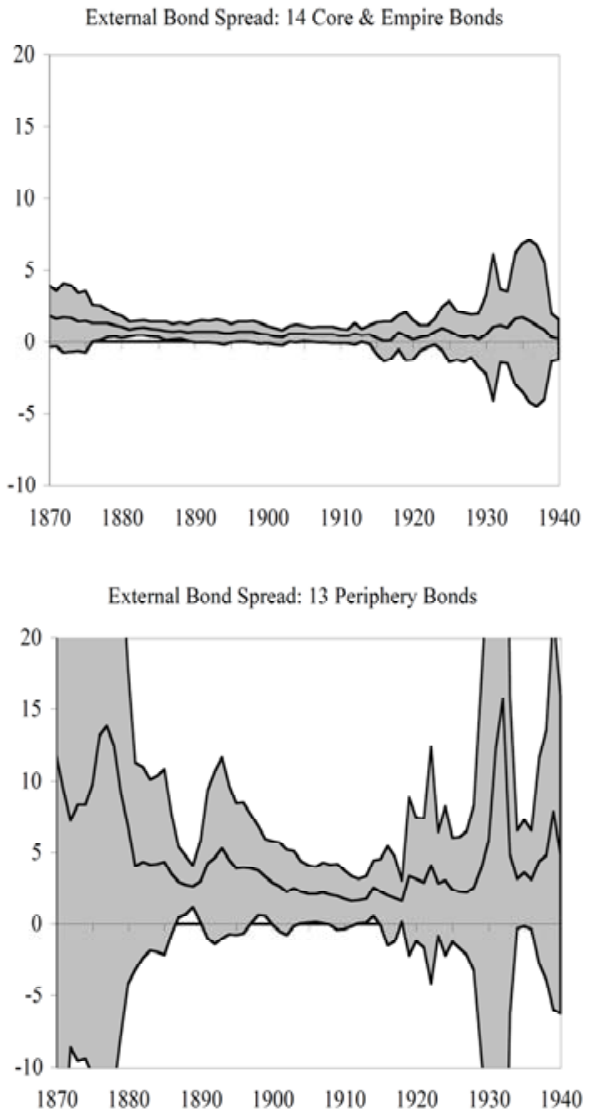

29

Notes: See note 57 Source: Global Financial Data.

Source: Obstfeld and Taylor (2004) Globalization and Capital Markets 


\section{Capital Mobility and the Incidence of Banking Crises}

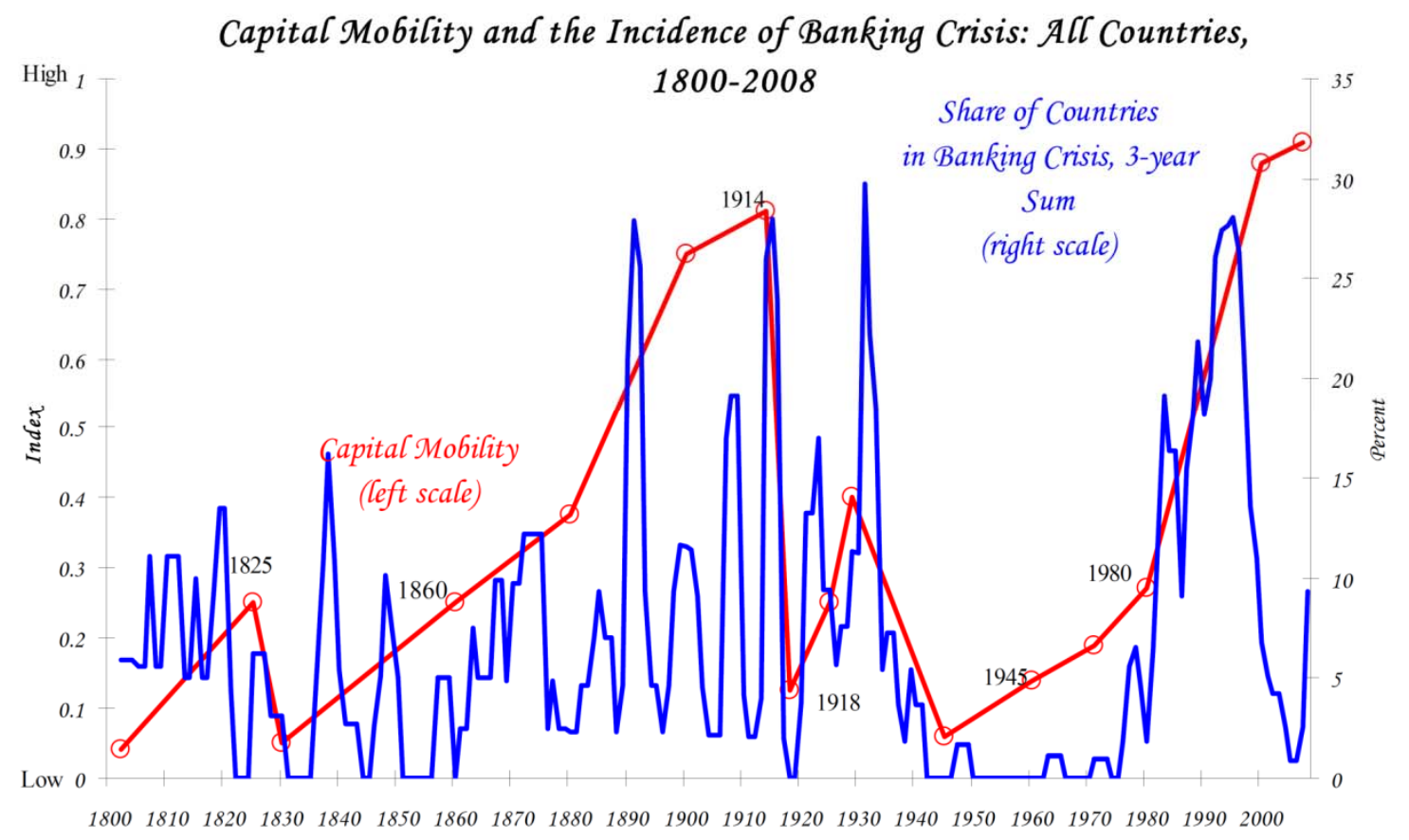

From: Reinhart Rogoff 2009. 


\section{Bond Yields in Eurozone}

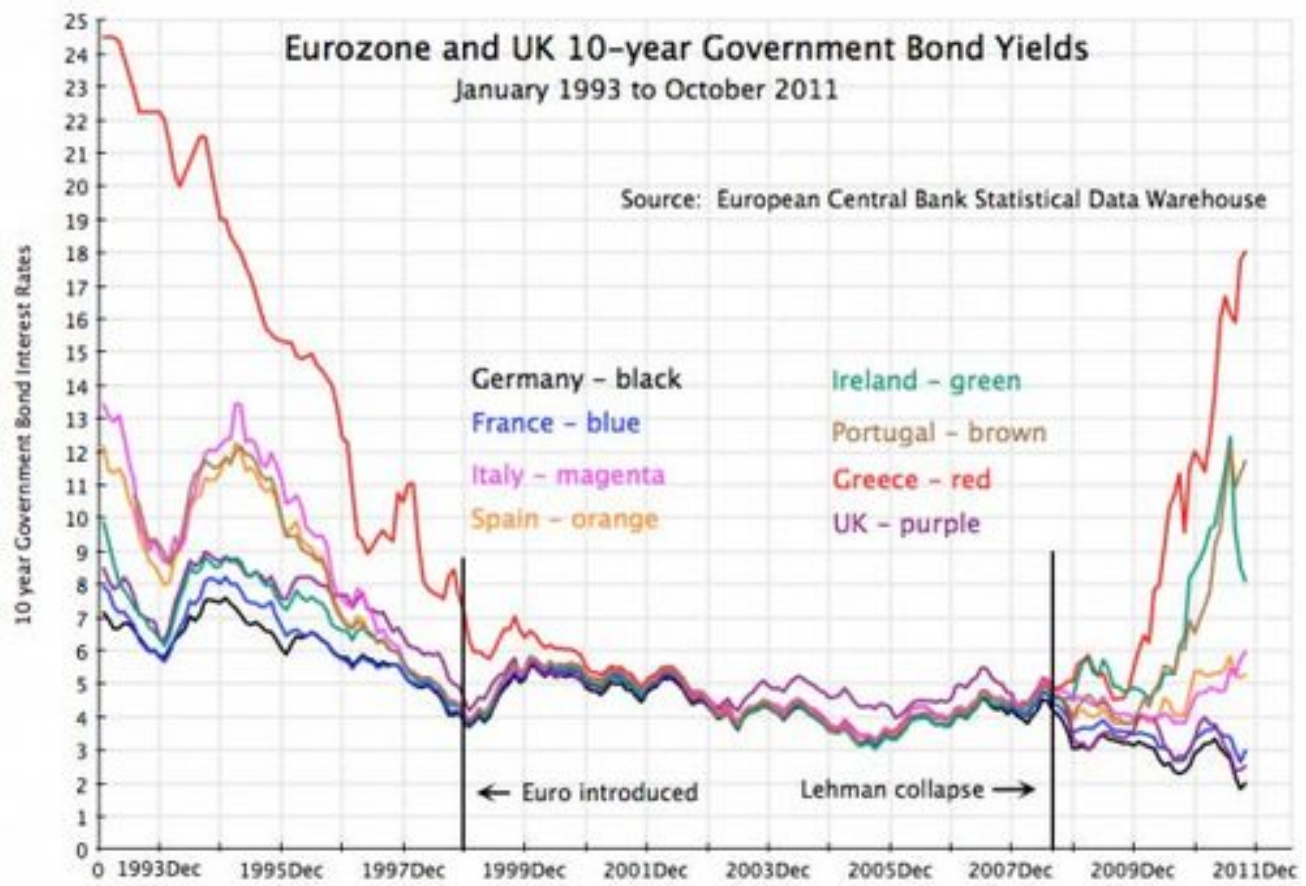




\section{Fiscal Positions in Eurozone}

General Government Net Borrowing/Lending 1990s (\% of GDP)

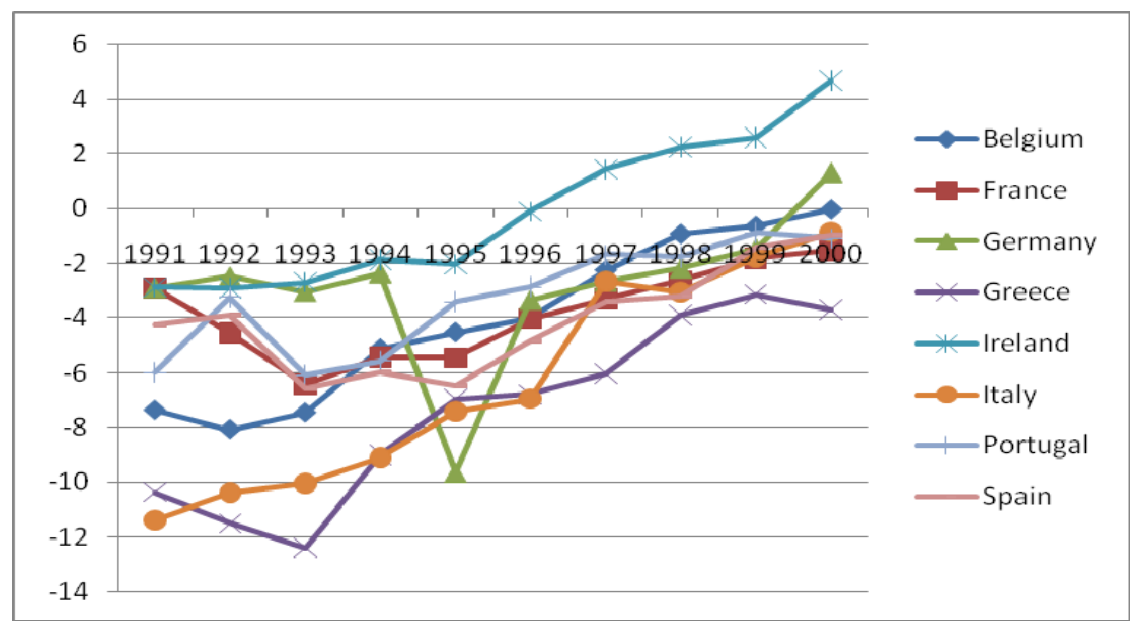

Source: IMF

General Government Net Borrowing/Lending 2000s (\% of GDP)

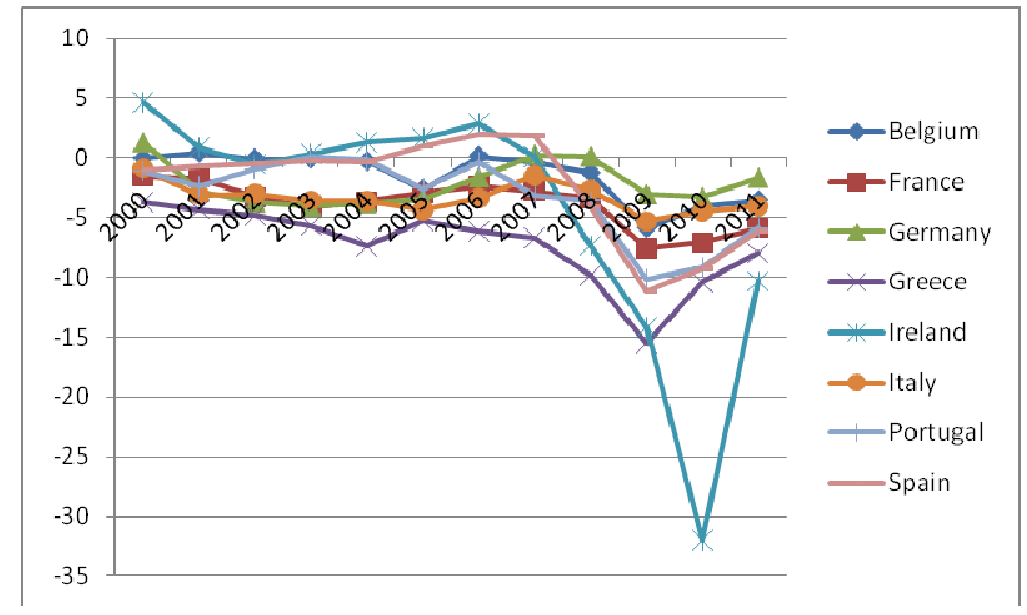

Source: IMF 


\section{Spain: Total Bank Credit to Domestic Borrowers}

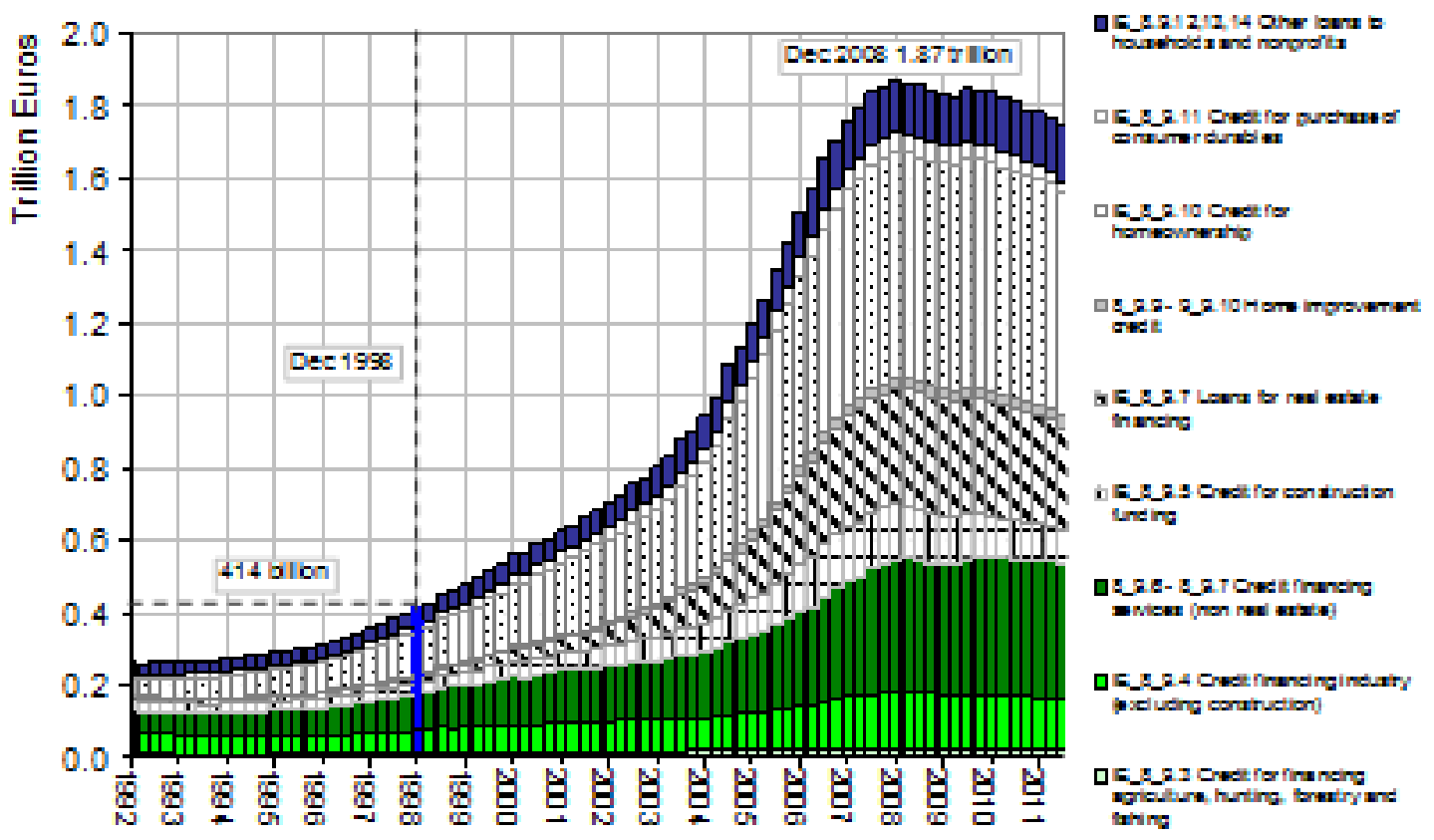

Source: Bank of Spain 
8.

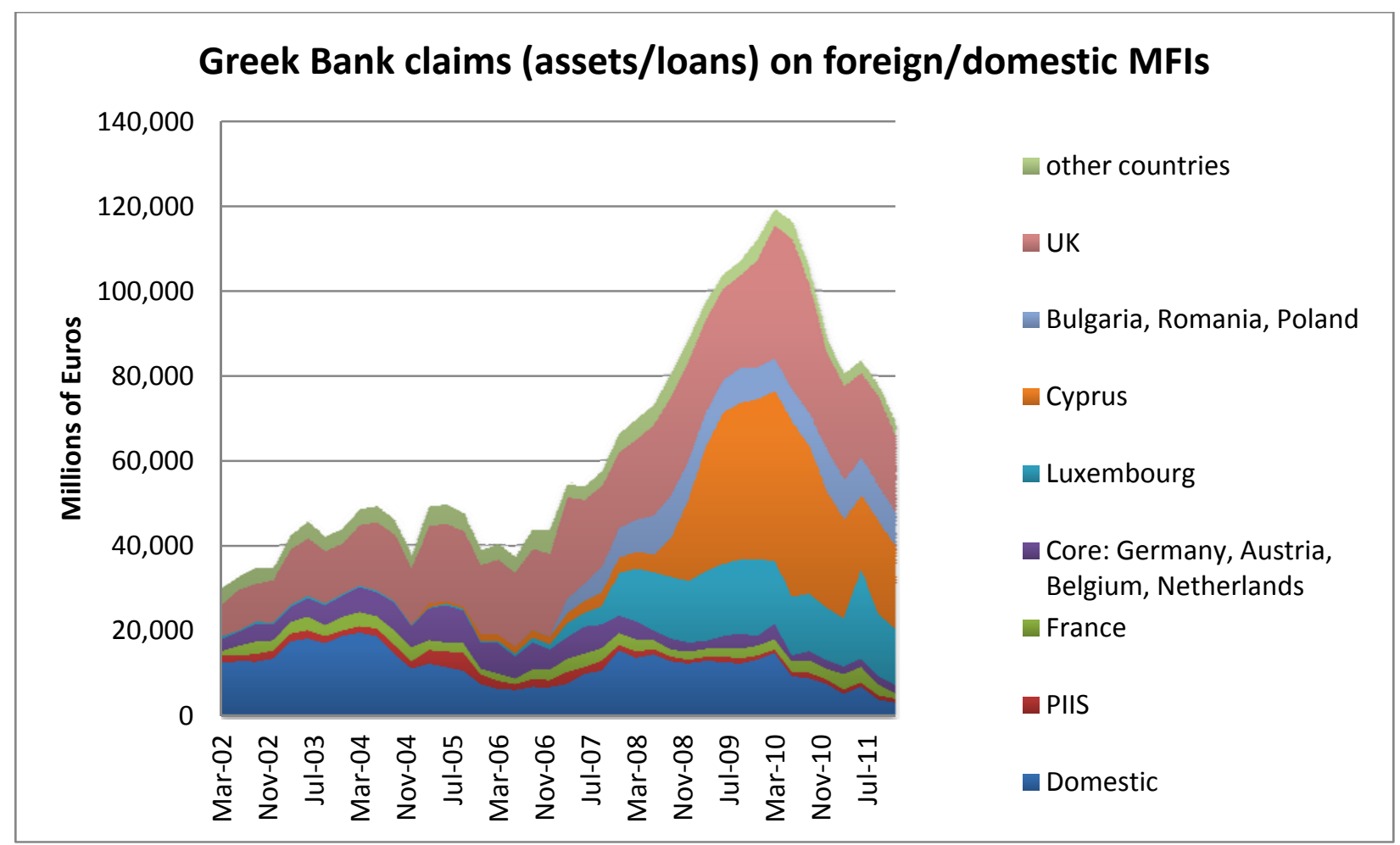

Source: Monovoukas 2012 and Bank of Greece statistics 


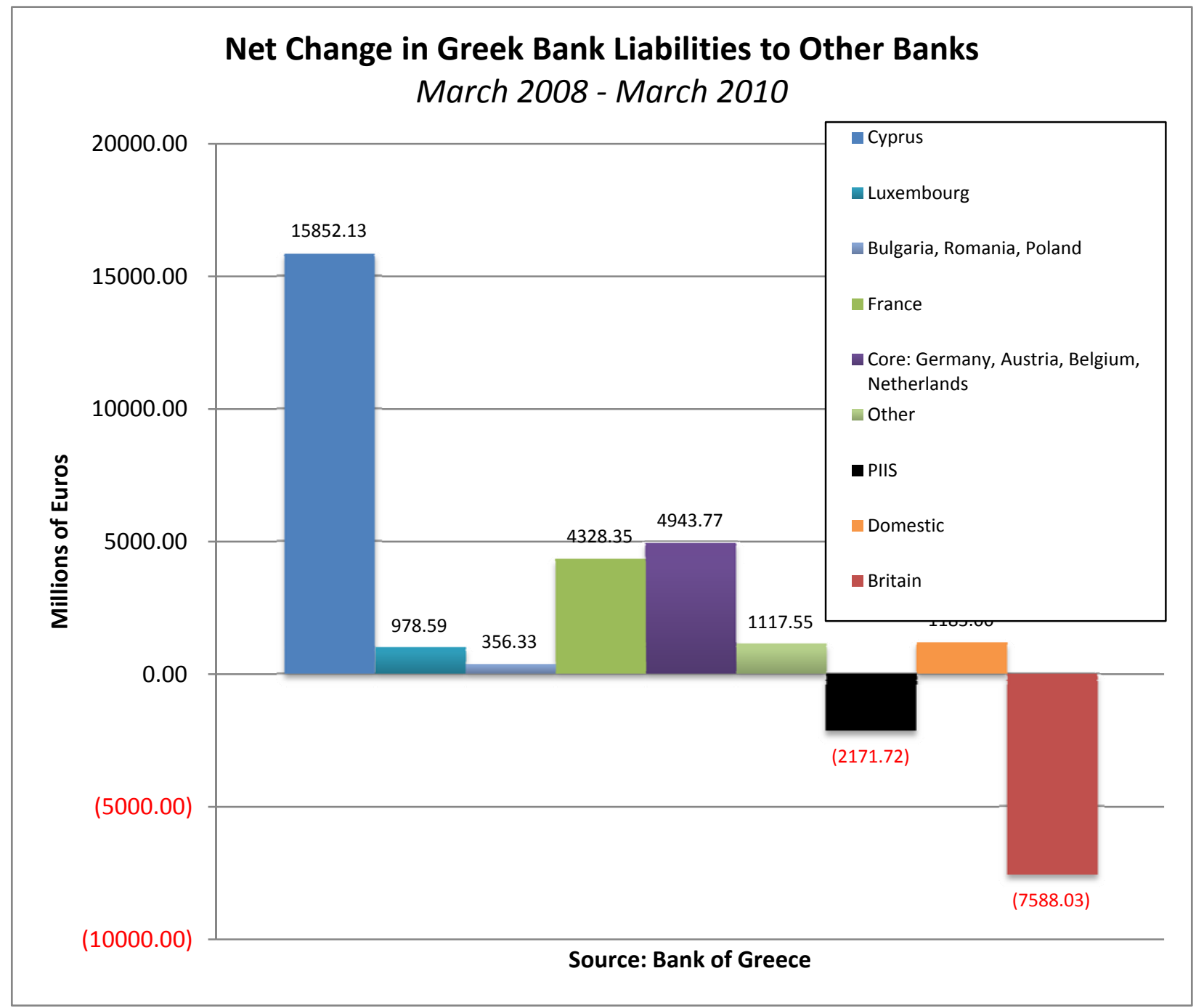

Source: Monovoukas 2012 and Bank of Greece statistics 


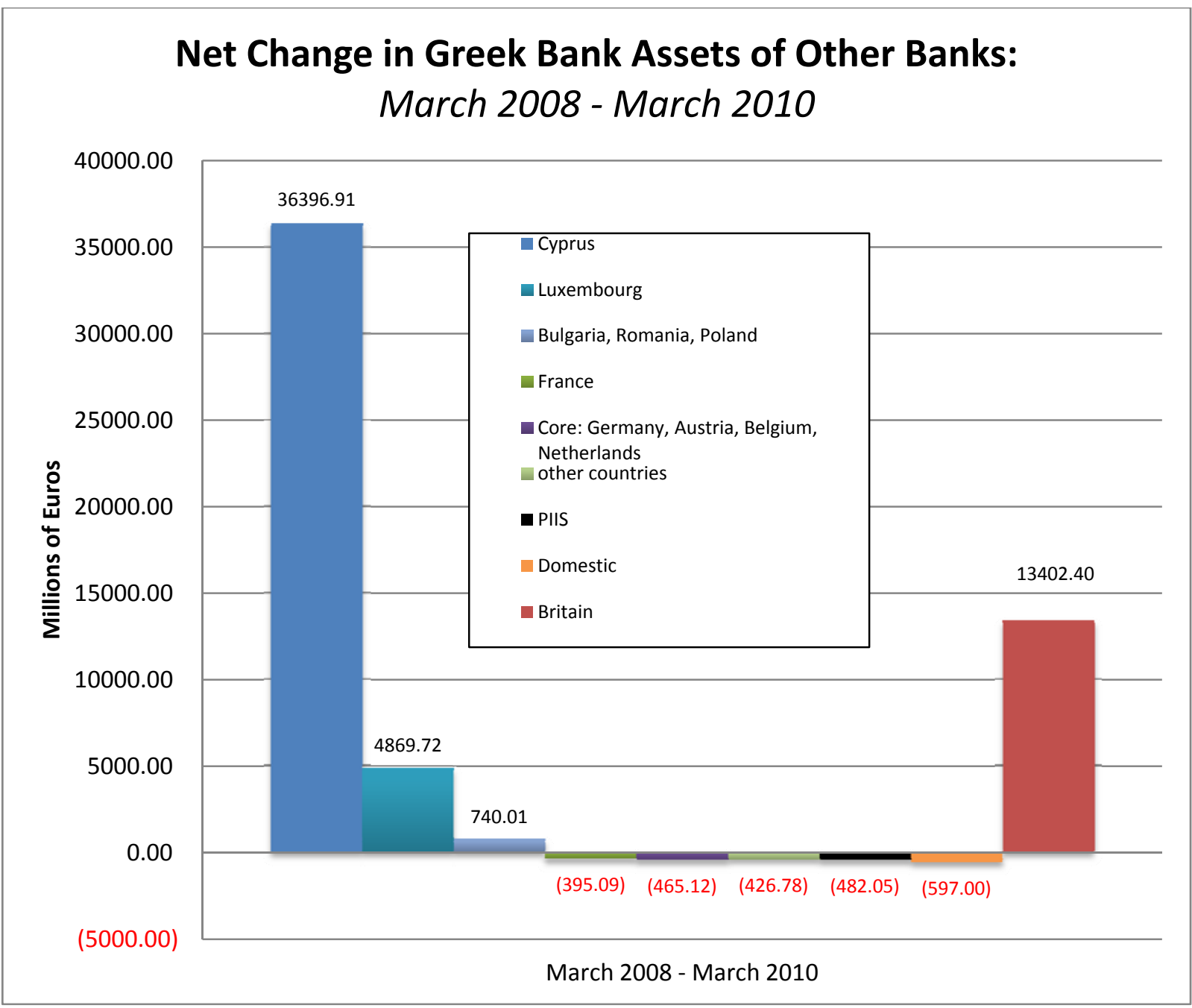

10

Source: Monovoukas 2012 and Bank of Greece statistics 
11. Public Debt as Share of GDP in some EMU countries (IMF Historical Database)

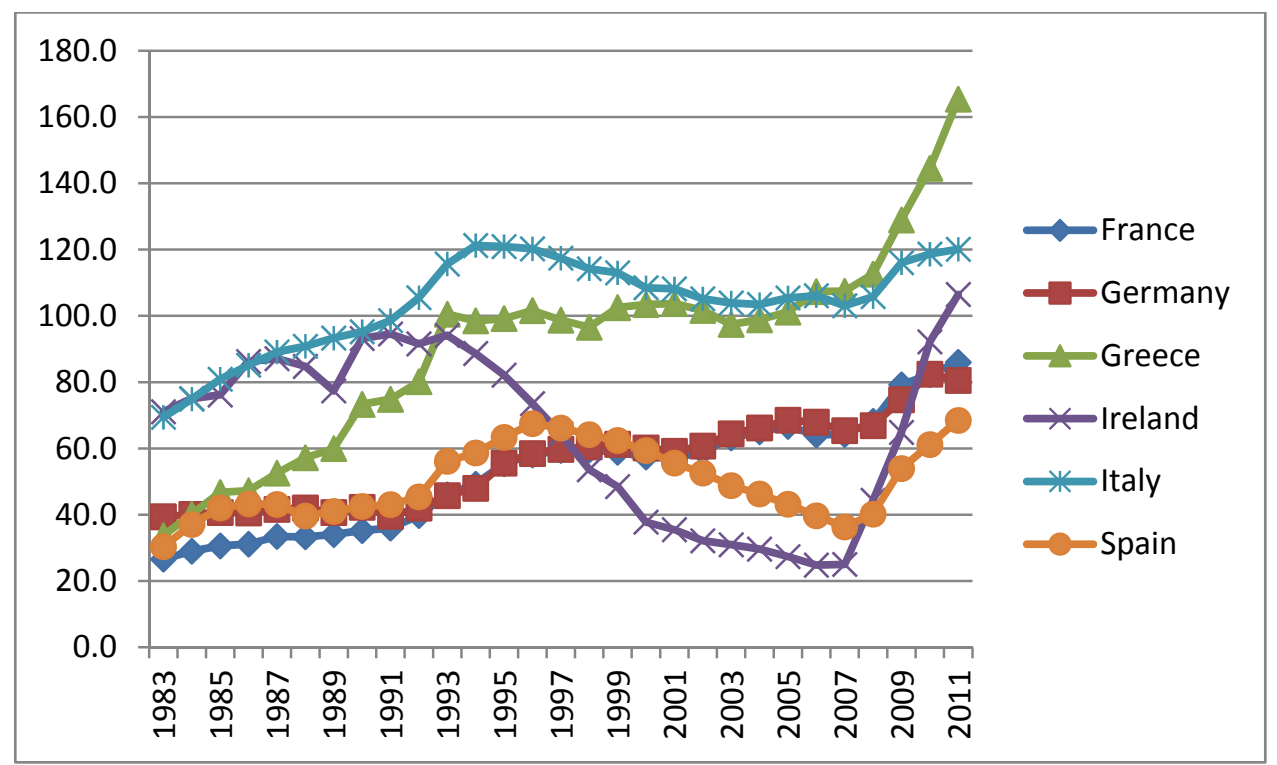




\section{Real GDP after Financial Crisis}

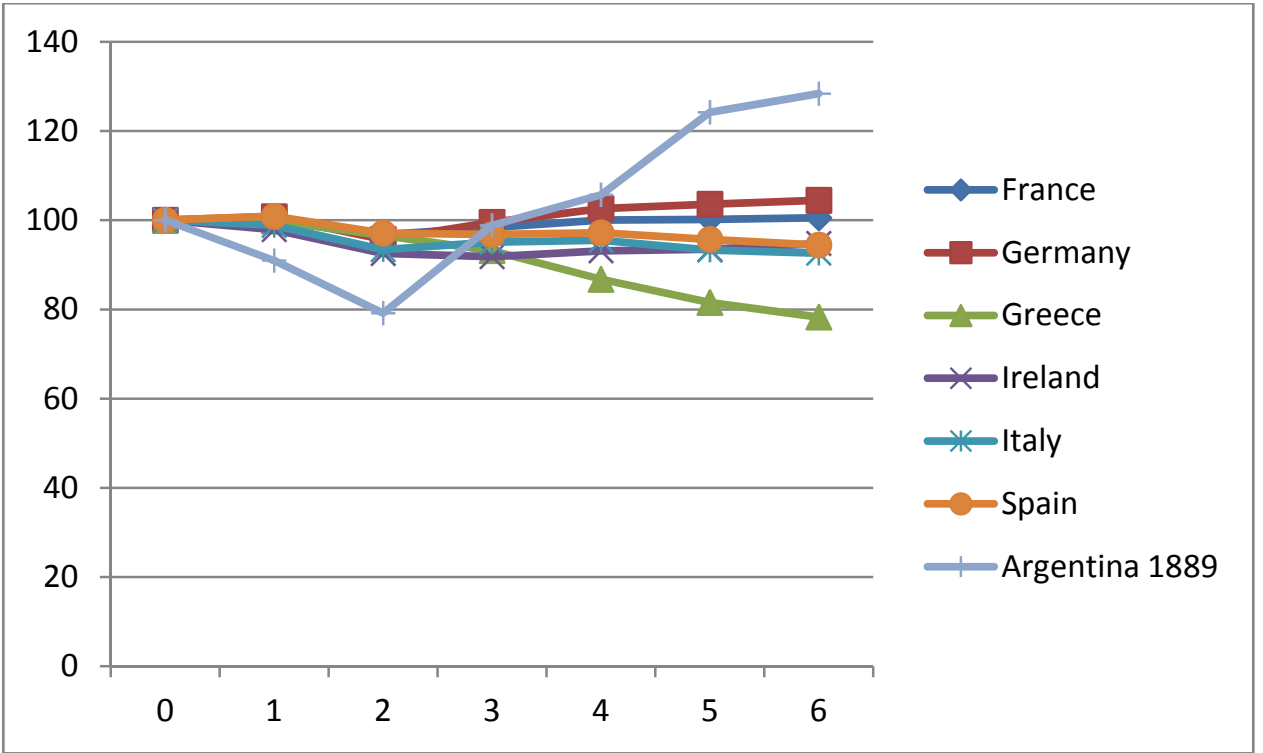

Source: Della Paolera and Taylor 2003 for Argentina after 1889; IMF for Europe after 2007. 